\title{
Survey on the types of nesting of Africanized honeybees in urban areas of semiarid regions and rationalization of swarm capture for the benefit of the community
}

\section{Levantamento sobre os tipos de nidificação de abelhas africanizadas em áreas urbanas do semiárido e racionalização da captura de enxames em prol da comunidade}

\author{
Ricardo Gonçalves Santos ${ }^{1 *}$; Dayson Castilhos²; Leandro Alves da Silva3; Daiana \\ da Silva Sombra ${ }^{4}$; Herica Girlane Tertulino Domingos ${ }^{5}$; Kátia Peres Gramacho ${ }^{6}$; \\ Lionel Segui Gonçalves ${ }^{7}$
}

\section{Highlights:}

Peak swarming of Africanized honeybee colonies in semiarid urban area occurred in April-September. Swarming was 250\% higher in April-September than in October-March.

Africanized honeybees are more selective when searching for permanent colony building sites.

Appropriate management techniques facilitate the capture of swarms in an urban area.

\begin{abstract}
Africanized honeybees (Apis mellifera L.) are abundant and widely adaptable insects that spread rapidly in tropical environments. However, their strong defensive instinct can lead to attacks on humans and animals, causing disturbances in cities. This study aimed to evaluate the nesting characteristics of Africanized honeybees in Mossoró, RN, to generate relevant information for the control of the population of these insects and prevent accidents in urban areas in the Brazilian Semiarid. This survey was conducted from April 2015 to March 2018. The following information on swarms was collected from 487 recorded occurrences: date of survey, structure of the bee site, occurrence of nesting, population size, defensiveness of the bees, and presence of queen and drones. Although the swarms reproduced throughout the year, the breeding of queens and drones increased in the rainy season (January-June). Peak swarming occurred in April-September, when there is greater availability of flowers in the region and the average ambient temperature is mild. The swarms adopted a generalist approach when choosing their nesting site, occupying structures such as tires, tree trunks, buckets, sewage, and cardboard boxes. Most swarms were found in open sites (exposed swarms). The Africanized honeybees were more selective when looking for a nest construction site than when looking for a temporary site for
\end{abstract}

1 Dr., Programa de Pós-Graduação em Ciência Animal, Universidade Federal Rural do Semi-Árido, UFERSA, Mossoró, RN, Brasil. E-mail: ricardogoncalvessantos12@gmail.com

2 Pós-Doutorado, Programa de Pós-Graduação em Ciência Animal, UFERSA, Mossoró, RN, Brasil. E-mail: dayson.castilhos@, yahoo.com.br

3 M.e, Programa de Pós-Graduação em Produção Animal, UFERSA, Mossoró, RN, Brasil. E-mail: leandrozootecnia@hotmail.com

4 Dra ${ }^{\mathrm{a}}$ Empresa de Assistência Técnica e Extensão Rural do Ceará, EMATER, CE, Russas, CE, Brasil. E-mail: daianasombra@, hotmail.com

5 Pós-Doutorado, Programa de Desenvolvimento Científico e Tecnológico Regional, Centro de Ciências Agrárias, UFERSA, Mossoró, RN, Brasil. E-mail: herica_tertulino@hotmail.com

6 Prof $^{a}$ Dr $^{\mathrm{a}}$, Apicultura, Centro de Ciências Agrárias, UFERSA, Mossoró, RN, Brasil. E-mail: katia.gramacho@ufersa.edu.br

7 Prof. Dr., Visitante, Programa de Pós-Graduação em Ciência Animal, UFERSA, Mossoró, RN, Brasil. E-mail: 1sgoncal@ffclrp. usp.br

* Author for correspndence 
landing and resting. The swarms were generally small (up to 20,000 bees) and not very defensive, which facilitated their rescue in populous urban areas.

Key words: Accident prevention. Apis mellifera L. Nesting. Swarm capture in urban areas.

\begin{abstract}
As abelhas africanizadas (Apis mellifera L.) são insetos prolíferos, apresentam enorme capacidade adaptativa e possuem rápida propagação em condições tropicais, no entanto, devido ao seu forte instinto defensivo, podem causar transtornos nas cidades pelo risco de ataques contra pessoas e animais. Diante disso, este trabalho teve como objetivo, avaliar características das nidificações das abelhas africanizadas em Mossoró-RN, podendo gerar informações relevantes para dar suporte a ações de controle populacional destes insetos e de prevenção à acidentes em áreas urbanas, de cidades no Semiárido Brasileiro. Esta pesquisa foi realizada durante o período de abril de 2015 a março de 2018. A partir de 487 ocorrências registradas, diversas informações foram coletadas sobre os enxames: data, estrutura do local onde as abelhas estavam alojadas, ocorrência de nidificação, tamanho populacional do enxame, defensividade das abelhas e presença de rainha e zangões. Os enxames investiram em reprodução durante o ano inteiro, contudo, a criação de rainhas e de zangões foi intensificada na estação chuvosa (jan-jun), enquanto o pico de enxameação ocorreu somente entre abril e setembro, época em que há maior disponibilidade de flores na região e quando a média de temperatura ambiental está amena. Os enxames foram generalistas quanto ao local de nidificação, pois ocuparam estruturas diversificadas como pneus, troncos de árvore, baldes, caixas de esgoto e de papelão, entre muitos outros. A maioria dos enxames foram encontrados em locais abertos (enxame exposto). As abelhas africanizadas apresentam maior grau de exigência quando procuram sítio para construção do ninho, ao invés de local provisório apenas para pouso e descanso. Os enxames foram geralmente pequenos (até 20 mil abelhas) e pouco defensivos, fato que facilitou o resgate de abelhas em áreas urbanas populosas.
\end{abstract}

Palavras-chave: Prevenção a acidentes. Apis mellifera L. Nidificação. Captura de enxames em zona urbana.

\section{Introduction}

In tropical environments, Africanized honeybees (Apis mellifera L.) are highly adaptable and widespread. Swarming behavior allows these bees to efficiently disperse in nature in times of food abundance, when the colony is divided in a process called reproductive swarming (Grozinger, Richards, \& Mattila, 2014), as well as in times of scarcity, when the swarm leaves its original site in a process called migratory or absconding swarming (Freitas, Sousa, \& Bomfim, 2007; Pereira et al., 2014).

These two processes, although highly adaptive for the survival and dispersion of bees, can cause serious problems in urban areas because of the risk of accidents caused by these insects (Baum, Tchakerian, Thoenes, \& Coulson, 2008; A. M. M. Santos \& Mendes, 2016). Africanized honeybees are extremely sensitive to sound disturbances, vibrations, and strong smells, which may result in intense attacks when they feel threatened (Brandeburgo \& Gonçalves, 1990; Breed, GuzmánNovoa, \& Hunt, 2004). Thus, although bees are not mechanical vectors or direct transmitters of diseases, they can become a nuisance in urban areas by generating public and social conflicts, especially when bee accidents result in human deaths (Ferreira, Almeida, Barraviera, \& Barraviera, 2012; Zaluski et al., 2014; A. M. M. Santos \& Mendes, 2016).

Despite the problems reported above, bees need to be protected as they are essential pollinators and thus, play a fundamental role in food production (Potts et al., 2016; Degrandi-Hoffman, Graham, Ahumada, Smart, \& Ziolkowski, 2019) and in maintaining the biodiversity of the ecosystem (Buchmann \& Nabhan, 2012; Wilson \& Carril, 2015; Hall \& Steiner, 2019). Understanding the nesting of bees, their characteristics (e.g., size and 
defensiveness), site preferences, and swarming behavior is important to develop populational control actions, preventing the extermination of bees by part of the human population and the government, while also protecting people and animals from accidents caused by bees in urban areas. This study aimed to evaluate the nesting characteristics of Africanized honeybees in Mossoró, RN, to generate relevant information for the control of the population of these insects and prevent accidents in urban areas in the Brazilian Semiarid.

\section{Materials and Methods}

This study was conducted in the Apiculture sector of the Animal Sciences Department of the Federal Rural University of the Semi-Arid (UFERSA), Municipality of Mossoró, RN, located in the western region of the state of Rio Grande do Norte. Mossoró $\left(5^{\circ} 11^{\prime} \mathrm{S}, 37^{\circ} 20^{\prime} \mathrm{W}\right.$, average altitude $=18$ $\mathrm{m}$ ) is located $281 \mathrm{~km}$ away from the state capital, Natal, and occupies an area of about $2100 \mathrm{~km}^{2}$, being the largest municipality in the state in terms of territorial area and the second most populous. The average annual temperature is around $27.5^{\circ} \mathrm{C}$, with a relative humidity of $68.9 \%$ and an average annual rainfall of $673.9 \mathrm{~mm}$ (Carmo et al., 1991). According to the Köppen climate classification, the climate of Mossoró is in the BSwh' group, that is, very hot and dry semi-arid tropical with rainy season occurring in the summer.

A partnership between the Federal Rural University of the Semiarid region (Universidade Federal Rural do Semi-Árido, UFERSA) and the Corporation of the Military Fire Brigade (Corporação do Corpo de Bombeiros Militar) of Mossoró allowed the capture and on site evaluation of wild swarms of Africanized honeybees from April 2015 to March 2018. The capture was requested by the residents of the city. In each occurrence, the following data on the swarms were recorded: date, structure of the site where the bees were found, nesting, estimated population size of the swarm, defensiveness of bees, and presence of queen and drones.
To estimate the number of bees, the swarms were captured by a suction device (Figure 1) and subsequently weighed together with the bee trap container (suction device can); the net weight of each swarm was obtained by subtracting the weight of the empty can from the total weight. Then, a sample of 50 individuals was weighed to obtain an estimate of the total number of bees in the swarm using the following formula:

$$
\mathrm{ENB}=\frac{50 \times \mathrm{NWS}}{\mathrm{WSB}},
$$

where ENB is the estimated number of bees; 50 is the fixed number of bees weighed per swarm; NWS is the net weight of the captured swarm (total of bees in grams); and WSB is the weight of the sample with 50 bees (in grams).

As it was not always possible to capture the swarm with the suction device, an alternative method to estimate swarm size, based on visual analysis by the researcher, was used. For this, five population levels were defined, namely: 1) $<10,000$ bees; 2) 10,000-20,000 bees; 3) 20,000-40,000 bees; 4) 40,000-60,000 bees; and 5) >60,000 bees. When the swarm sucking device and ENB formula could not be used to provide an estimate of the total number of bees in the swarm, the swarm population was placed in one of these five population levels.

The defensive behavior of the swarms was classified into three levels (low, medium, and high defensiveness) based on the defense reaction of the bees when the swarm was captured. For this, a methodology was adapted from the arbitrary scale used by Souza, Gramacho and Castagnino (2012) (Table 1).

The Tukey test was used to compare the data on the monthly occurrence of swarms, population size, and defensive behavior. The student's t-test was used to compare between swarms in open (exposed swarm) and closed (protected swarm) spaces, as well as between swarms with and without the queen and drones in the dry versus rainy season. In both tests, $p \leq 0.05$ was considered significant. 

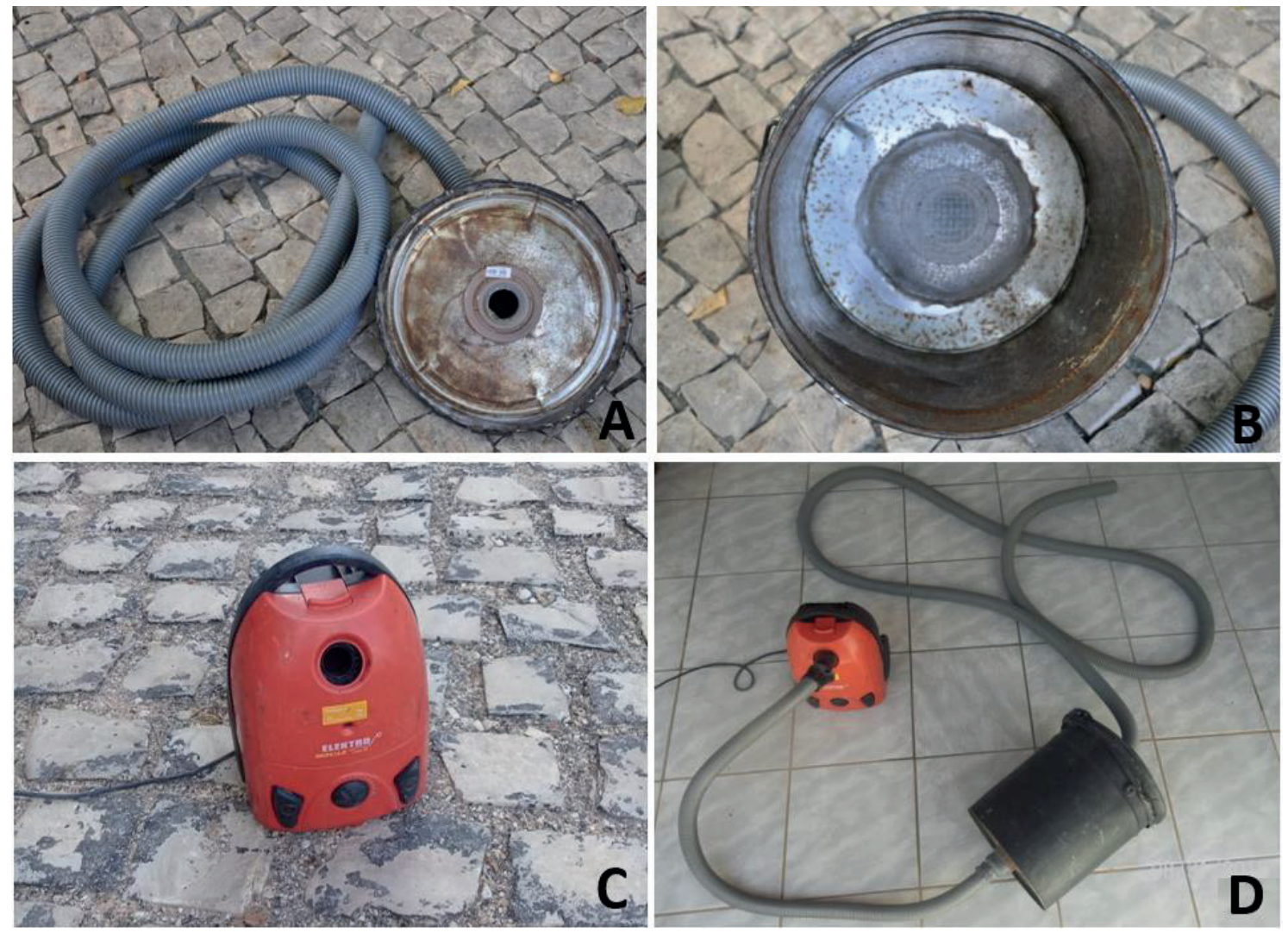

Figure 1. Swarm Suction Device. Suction device prepared by the SOS Abelhas Project Team to capture wild swarms of Africanized honeybees (Apis mellifera L.) in the city of Mossoró, RN, Brazil.

A) Lid of the bee trap container with a 3-m hose, through which the bees are sucked; B) 20-L cast iron container for trapping the bees, with a steel mesh at the bottom, which prevents the bees from following the path of the suction force, keeping them trapped inside the container; C) Electric vacuum cleaner with a power of 1200 watts; D) Mounted swarm sucking device with its parts connected.

\section{Table 1}

Subjective analysis to assess defensive behavior during the capture of wild swarms of Africanized honeybees (Apis mellifera)

\begin{tabular}{ccl}
\hline Category & Defensiveness & General behavior of bees during capture \\
\hline 1 & Low & $\begin{array}{l}\text { Bees attack occasionally or do not attack, do not chase people and animals, and gen- } \\
\text { erally remain calm, even with the application of little or no smoke for their control. }\end{array}$ \\
\hline 2 & Average & $\begin{array}{l}\text { Although bees attack more frequently, hit the observer's mask, and occasionally } \\
\text { chase people or animals, they are easily controlled with the application of smoke, } \\
\text { allowing normal handling of the swarm during capture. }\end{array}$ \\
\hline 3 & $\begin{array}{l}\text { Bees attack in a generalized way, with a large number of bees hitting the observer's } \\
\text { mask, attacking/chasing people and animals in the vicinity and over long distances; } \\
\text { it takes time to control them with the application of smoke, forcing the handler to } \\
\text { eventually interrupt the capture for approximately 1 hour to control the bees, or even } \\
\text { reschedule the capture for another day and time. }\end{array}$ \\
\hline
\end{tabular}

Source: Methodology developed by the author based on an arbitrary scale used by Souza et al. (2012) to assess the defensive behavior of Africanized honey bee colonies (A. mellifera). 


\section{Results and Discussion}

From April 2015 to March 2018, 487 wild swarms of Africanized honeybees were reported in the urban area of Mossoró. The incidence of such swarms peaked between April and September, with total values of $54,55,66,68,56$, and 50 swarms in each month, respectively. These values were statistically equal $(p \leq 0.05)$. The total monthly values correspond to the sum of the values obtained in the three years of survey. Only June and July showed a statistically significant difference when compared to January, February, October, November, and December. This study classified the period of highest swarm incidence (April-September) as the swarming peak in the city of Mossoró, with 349 records of swarms of Africanized honeybees, while there were only 138 occurrences in the period of lowest swarm incidence (October-March). Figure 2 shows the average monthly number of wild swarms recorded throughout the year.

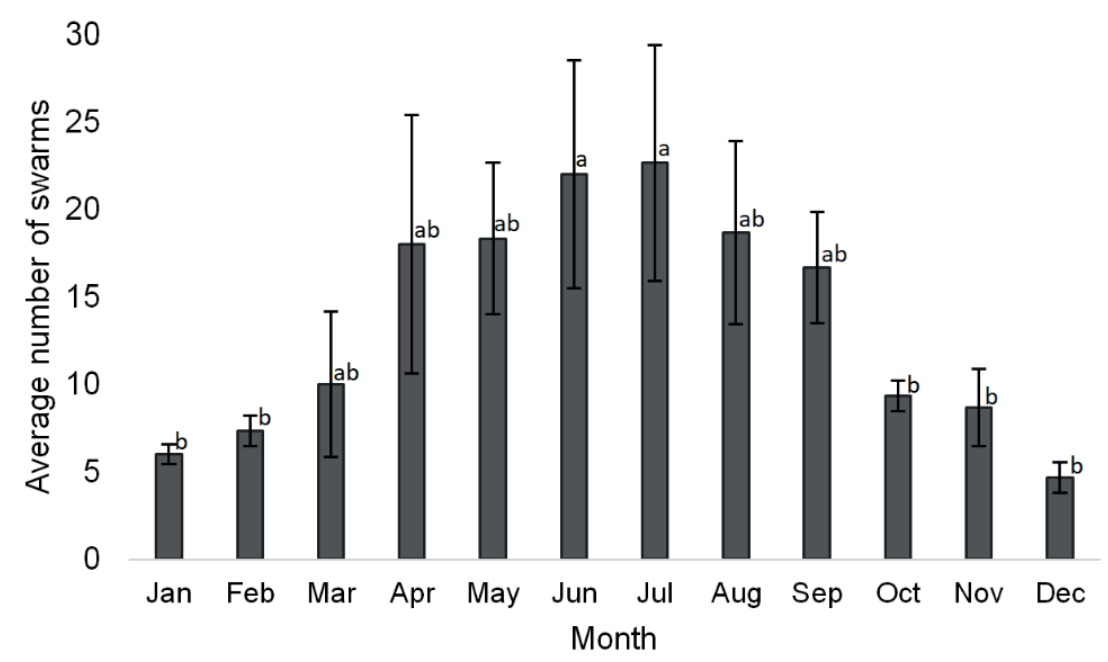

Figure 2. Average monthly occurrence of wild swarms of Africanized honeybees (Apis mellifera L.) throughout the year in the urban area of Mossoró, RN, Brazil ( $\mathrm{n}=487)$. Collection period: April 2015 to March 2018.

*Equal letters do not differ statistically from each other by the Tukey test at the $5 \%$ probability level.

The significant increase in swarming incidences between April and September was possibly because of the greater supply of food as there is a great variety of native plants in bloom in the region during this period of the year (Maia-Silva, Silva, Hrncir, Queiroz, \& Imperatriz-Fonseca, 2012). In times of abundant food, the workers work ceaselessly, and as the queen is better fed, more eggs are laid. Consequently, the swarms develop and the population considerably increases, sometimes reaching more than 100,000 bees. During this process, the colonies create several queens and divide, releasing several swarms in nature in a process called reproductive swarm (Grozinger et al., 2014).

Another important aspect is the climate of this study area, characterized by very high temperatures, which hamper the thermal homeostasis of the colonies and cause physiological disturbances in the bees (Domingos \& Gonçalves, 2014; Domingos, Sombra, Santos, Gramacho, \& Gonçalves, 2018). Africanized bees swarmed more when the environmental conditions in the region are mild. When this study was conducted (April 2015 to March 2018), the average environmental 
temperature during the months with more swarms (April-September) was $27.23^{\circ} \mathrm{C}$, whereas that of the period with less swarms (October-March) was $28.49^{\circ} \mathrm{C}$. The marked increase in swarming when environmental conditions were favorable (with food availability and mild ambient temperature) suggests that the swarming peak (April-September) in Mossoró is probably a result of reproductive swarming. Although swarms also migrate from the Caatinga to the municipality of Mossoró, which was herein evidenced by the occurrence of small swarms without drones at the period of greatest scarcity of floral resources in the Caatinga (October-January), this migration or absconding behavior was not very significant in the city as it was not enough to cause a swarming peak during this period.

Toledo et al. (2006) evaluated the occurrence of swarms in the urban area of Maringá, PR, and observed two swarming peaks in the region, one in March-April and the other in August-September, which they identified as peak absconding swarming and peak reproductive swarming, respectively. Zaluski et al. (2014), however, only found one peak incidence of swarms in the urban area of Botucatu, SP, in February-March. Nascimento (2019) stated that the period of swarming of Africanized honeybees in the metropolitan region of Aracaju, SE, is in September-February. Silva and Barreto (2016), however, reported a wide variation of the peak incidence of swarms in the Greater São Paulo area, SP. Since Africanized honeybees are widely adaptable, swarm behavior and survival strategies can vary greatly, depending on the environmental conditions of the region where the bees live, as the swarming dynamic of this species varies according to environmental characteristics. This demonstrates this species' high adaptive capacity.

Part of the swarms found in the urban area of Mossoró may have come from swarming of the colonies in the commercial apiaries located on the properties surrounding the city or they may have resulted from the absconding of their nests located in the native vegetation of the Caatinga biome. The latter hypothesis is more likely to occur in the dry season in the region. Freitas et al. (2007) stated that only $5 \%$ of Africanized honey bee colonies remain in semi-arid areas of Northeast Brazil throughout the year, which may be due to the attacks of ants (Camponotus sp.), lack of food (nectar and pollen), or lack of water in the dry season. The remaining colonies migrate to coastal areas, which are more humid and have vegetation rich in flowers. However, unlike the entire northeastern coast, which has dense vegetation formed by humid areas of mangrove and Atlantic forest, the coastal region close to Mossoró, located just $40 \mathrm{~km}$ from the city, has scarce floral resources for the bees. This is because of the typical vegetation of this environment, composed mainly of xerophilous plants, which have slow vegetative growth and reproduction in a short period of the year and are adapted to survive in very hot and dry areas (Alves, Araújo, \& Nascimento, 2009; Loiola, Roque, \& Oliveira, 2012).

Thus, while Caatinga and the coast do not provide ideal conditions for bees, the cities of the Brazilian Semiarid Region, such as Mossoró, are attractive because they are rich in nesting sites with great supply of food in commercial establishments, gardens, flowerbeds, and irrigated vegetable gardens, as well as exotic trees that offer food and nesting options in buildings and sites shaded by dense and perennial canopies of plants such as mango (Mangifera indica), Indian almond (Terminalia catappa), weeping fig (Ficus sp.), and neem (Azadirachta indica). Lopes et al. (2011), Santos, Domingos, Gramacho and Gonçalves (2017) stated that tree canopies facilitate the temperature control of Africanized honeybees' nests in the semiarid conditions of Northeast Brazil, providing better development of swarms.

Africanized honeybees showed generalist behavior when choosing their nesting environment as swarms were found in a huge variety of structures composed of materials of different characteristics, such as trees, hollow trunks, cabinets, tires, termite mounds, pipes, and roofs and ceilings of houses 
(Figure 3). Because of the devastation and the vegetative characteristics of the deciduous plants of the Caatinga, Africanized honeybees might not have the same opportunities in the semiarid region as those offered in urban areas such as Mossoró, which provides nesting conditions to the colonies so that they can achieve thermal homeostasis.
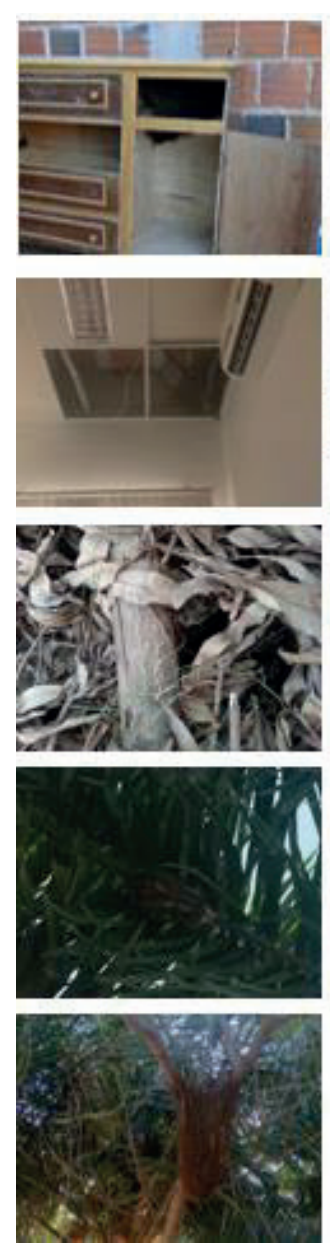
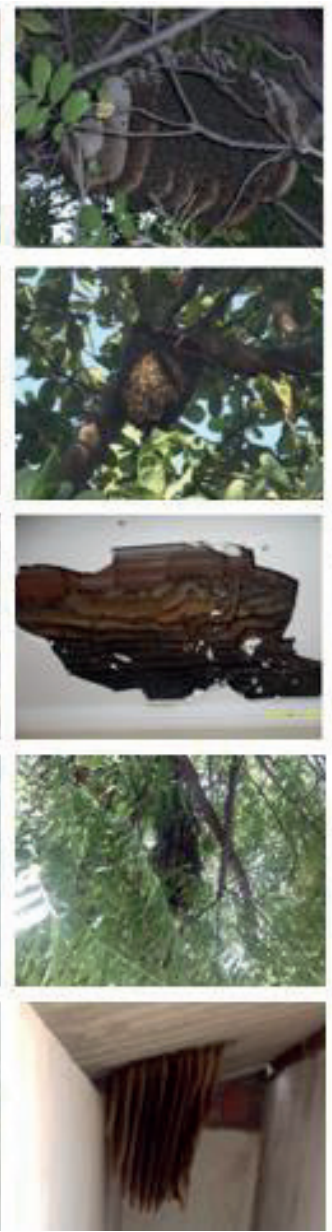
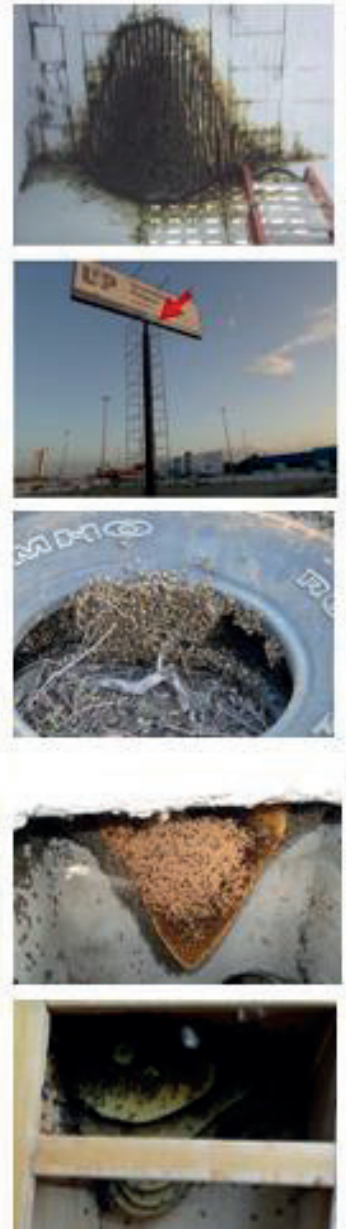
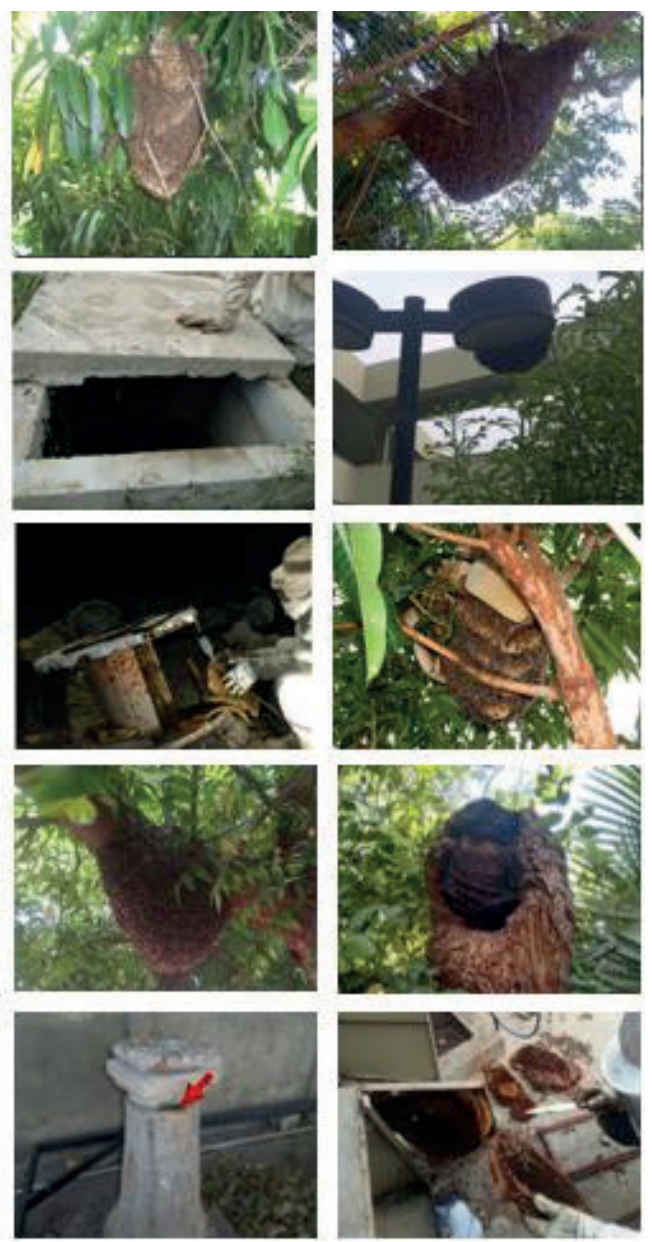

Figure 3. Wild swarms of Africanized honeybees (Apis mellifera L.) found in sites with different structures in the urban area of Mossoró, RN, Brazil.

Of the total 487 occurrences, it was possible to distinguish the nesting situation in 449 cases, with 277 of them having a formed nest, differing significantly $(p \leq 0,05)$ from the 172 records that were classified as non-settled swarms or flying swarms (Figure 4A). Similarly, 156 swarms were in a closed environment (swarm protected in a cavity) and 293 swarms were in an open environment (exposed swarm) (a statistically significant difference at $p \leq 0.05$ ) (Figure 4B). 


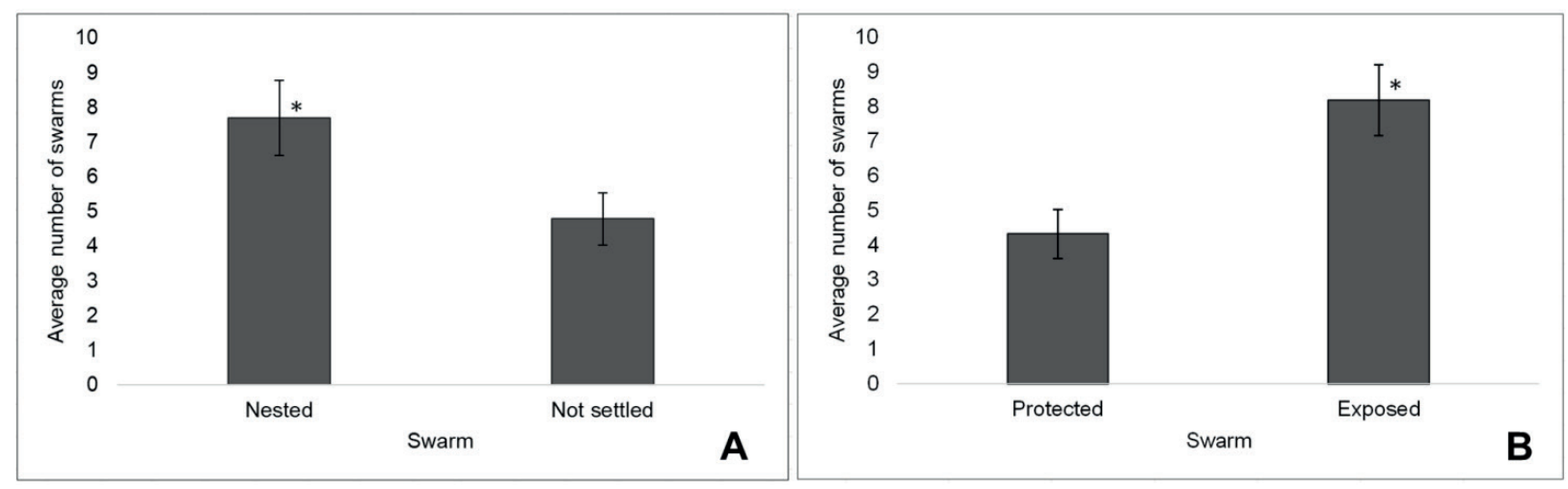

Figure 4. Wild swarms of Africanized honeybees (Apis mellifera L.) found in an urban area of Mossoró, RN, Brazil. A) Swarms nested and not settled; B) Swarms in open (exposed swarm) or closed (protected swarm) sites. * Statistically different.

The proportion of swarms found with or without nesting in the urban area may give clues about the work dynamics while working in this activity. It is important to consider that swarms protected in cavities are more difficult to capture, requiring a greater effort from the handler to proceed with the capture. This is because it is usually necessary to break the ceilings of houses, remove roofs, dismantle structures, among other actions. In contrast, exposed swarms are usually easier to capture because they are already in an open environment and are visible to the handler. Therefore, in addition to increasing the knowledge about the behavior of Africanized honeybees in cities, our findings should be considered from a practical point of view when planning a swarm collection program in urban locations.
As they adopt a generalist approach when choosing nesting sites, Africanized honeybees can occupy both cavities and exposed sites (MalerboSouza, Nogueira-Couto, \& Couto, 2002; Toledo et al., 2006; Silva \& Barreto, 2016). That is, the choice of Africanized honeybees is a reflection of the nesting possibilities or alternatives found in the environment they exploit in cities. In contrast, bees of European origin are rarely found nesting outdoors (Lipinski, 2019).

Although most of the swarms were found in open sites (exposed swarms) (Figure 4B), those in closed sites (protected swarms) nested more (133) when compared to flying swarms in this type of environment (23). In open sites, however, a similar number of nesting and flying swarms was found, with 144 and 149 occurrences, respectively. Table 2 shows these values as a percentage.

Table 2

Wild swarms of Africanized honeybees (Apis mellifera L.) nested and non-settled found in open (exposed swarm) or closed (protected swarm) sites in the urban area of Mossoró, RN, Brazil. Collection period: April 2015 to March 2018

\begin{tabular}{lcc}
\hline \multirow{2}{*}{\multicolumn{1}{c}{ Swarm }} & \multicolumn{2}{c}{ Site (\%) } \\
\cline { 2 - 3 } & Open & Closed \\
\hline Nested (Colony) & $32.07 \mathrm{aA}$ & $29.62 \mathrm{aA}$ \\
Flying (non-settled) & $33.18 \mathrm{aA}$ & $5.12 \mathrm{bB}$ \\
\hline
\end{tabular}

*Average followed by the same lowercase letter (in the rows) and uppercase letter (in the columns) do not differ statistically from each other based on the Tukey test at the $5 \%$ probability level. 
The difference between the number of swarms with a nest and the number of flying swarms observed in a protected environment suggests that when Africanized honeybees look for a site to build their colony, they are more selective than when looking for a temporary site only for landing and resting. This greater level of demand when choosing a site to build their nest may be because of their instinct of protection against natural enemies as a nest with stocks of honey and pollen and abundant offspring attract several types of predators in search of food (Kasperek, Paleolog, Olszewski, Borsuk, \& Strachecka, 2012; Foss, 2015). This selective preference of nesting sites may also ensure that bees achieve thermal control inside the colony more easily since the offspring depend on rigorous thermoregulation to properly develop (Kleinhenz, Bujok, Fuchs, \& Tautz, 2003). Swarms settled in a temporary site, however, seem to be less protected against predators (Winston, 1987) and have less control of thermoregulation inside the cluster, which often has higher temperatures, as in these cases the thermal control is more flexible because of the absence of offspring (Stabentheiner, Kovac, \& Brodschneider, 2010). Moreover, these swarms are less defensive because they do not yet have a defined site, a fully formed colony, nor offspring and food stored to protect (Winston, 1987; Sá \& Sousa, 2019).

Figure 5A shows the percentages of the estimated population size from a sample of 413 captured swarms that could be assessed. Most swarms had a small population size. A total of 127 swarms had up to 10,000 bees; 144 had 10,000-20,000; 87 had 20,000-40,000; 39 had 40,000-60,000; and the remaining 16 swarms had more than 60,000 . Although the number of swarms with up to 10,000 bees is similar to that with $10,000-20,000$ bees, these two population size ranges significantly differed from the others $(p \leq 0.05)$.
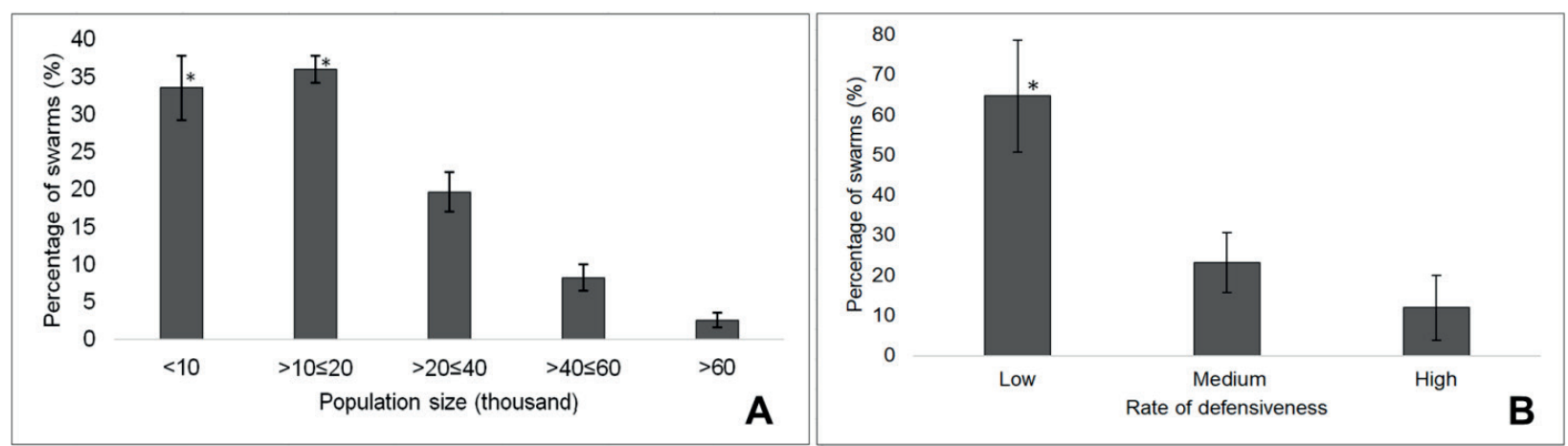

Figure 5. Wild swarms of Africanized honeybees (Apis mellifera L.) in an urban area of Mossoró, RN, Brazil, with different population sizes proportional to the number of bees per range being evaluated (A) and classified to the level of defensiveness during the capture (B). Collection period: April 2015 to March 2018.

*Statistically different based on the Tukey test at the 5\% probability level.

Although swarms with larger population sizes were observed throughout the year, they were commonly found in the period of greatest flow of nectar and pollen in the region, mainly between May and July. Moreover, the variation observed in the population size of the swarms, even at the same period, was certainly influenced by the particularities of the area as the site where a swarm is settled can be decisive for the growth of the colony, considering that, according to Nisbet, Güler and Biyik (2019), different environmental conditions are the main cause of the phenotypic behavioral differences observed between colonies. These authors stated that the location of the swarms 
interferes with the adult bee population, production of offspring, honey, and wax, as well as the foraging behavior of the bees.

Larger and more developed swarms were frequently found in protected sites, such as ceilings of houses, water tanks, or sewers, probably because of the longer time it took for people to detect them in these sites. This enabled the growth of these swarms. Moreover, unlike the exposed swarms, swarms settled in cavities may have benefited from the reduction of energy expenditure to achieve thermal control of the nest area, managing to maintain the thermal homeostasis of the colony more easily, as reported for swarms of $A$. mellifera nested in cavities (Foss, 2015; Lipinski, 2019). When bees manage to save time and energy in the thermoregulatory processes of the colony, the development and production parameters significantly improve as in these cases, more energy will be available for other tasks such as foraging, thus increasing the productive and expansion capacity of the swarms (Lopes et al., 2011; Santos et al., 2017; Domingos et al., 2018).

It was possible to assess the level of defensive behavior of 137 swarms during the capture. Most swarms showed low defensiveness (85 swarms), significantly exceeding $(p \leq 0.05)$ the number of swarms classified as having medium defensiveness (33 swarms) and high defensiveness (18 swarms). The percentage of swarms classified in the different categories of defensive behavior is shown in Figure 5B.

The correct management of wild swarms of Africanized honeybees settled in an urban environment is essential to ensure their safe capture, aiming at the well-being of people and animals nearby. For this, the adequate handling of swarms with smoke is paramount, which we successfully managed when capturing wild swarms of Africanized honeybees settled in urban areas of Mossoró.

Previous studies have indicated that swarms settled in hot sites are more defensive. Brandeburgo and Gonçalves (1990) subjected colonies from Ribeirão Preto, SP to the conditions of the warmer and more humid site Recife, PE and vice versa; they found that the colonies from Ribeirão Preto placed in Recife were consistently more defensive, whereas the colonies from Recife behaved less aggressively when they were settled in Ribeirão Preto. This clearly demonstrates the strong influence of environmental factors on the behavior of bees.

Temperature is positively correlated with the aggressiveness, which indicates a greater activity of defense of the colony in warmer cities or periods (Brandeburgo \& Gonçalves, 1990; Mello, Silva, \& Natal, 2003). Considering the conditions of Jaboticabal, SP, Malerbo-Souza et al. (2002) did not find defensive swarms which was also found by Brandeburgo and Gonçalves (1990). For these authors, the observed low defensive behavior may be because of the milder environmental conditions in Southeastern Brazil. In Mossoró, despite the high environmental temperature throughout the year, the large number of swarms classified as having low defensiveness can be attributed to the correct handling, mainly by applying the appropriate amount of smoke for a sufficient time to calm the bees. The low defensiveness is also because of the size of the swarms, as the lowest values were found in populations of less than 20,000 bees (Figure 5A). In general, the small and low defensive swarms reported in the urban area of Mossoro facilitated the capture on busy sites of the present study. These findings are useful for understanding the behavior and biology of Africanized honeybees in cities in addition to providing fundamental practical insights that must be considering when planning projects for collecting swarms in urban locations.

Although the swarms in Mossoró focused on the creation of queens and drones throughout the entire year, the production of these individuals increased during the rainy season (typically January-June). However, it is worth mentioning that the swarming peaks recorded were not limited to this rainy period (see Figure2). The percentage of swarms with a queen 
in the rainy season (199 swarms) was statistically equal to the percentage of swarms with a queen in the dry season (176 swarms). This is justified by the fact that the queen's permanence in the swarm is crucial for its survival, considering that she keeps the swarm cohesive using her pheromones and is the only fertile female in the colony. The queen, being the mother of all individuals in the colony, is responsible for half of the genetic information that is passed on to her daughters and for the entire genome that is inherited by the drones. Therefore, each colony is led by a reproductive queen and, thus, bee colonies are highly dependent on the queen's fertility (Brutscher, Baer, \& Niño, 2019).

Only a few cases of swarms without a queen have been reported. A total of 127 swarms with drones were recorded in the rainy season and 44 were recorded in the dry season (significantly different at $p \leq 0,05)$. The permanence of the drones throughout the dry period is probably due to the large supply of food (areas with flowers) in the city, gardens, squares, parks, cemeteries, flowerbeds, and irrigated vegetable gardens, as well as exotic trees that offer pollen and nectar in the most critical period of the year.

\section{Conclusions}

We conclude that Africanized honeybees have good conditions of survival in cities with hot and dry climate, such as those in the Brazilian Semiarid Region, where there is a high diversity of nesting sites, exotic trees with dense canopies, and abundant food. Although the breeding of queens and drones in the colonies increases during the rainy season, the swarming peak of the colonies occurs only between April and September, covering the end of the rainy season and the beginning of the dry season. In this period, there is an average increase of $250 \%$ in swarming compared with the period with the lowest incidence of swarms (October to March).

Although swarms adopt a generalist approach when choosing their nesting sites, Africanized honeybees are more selective and, thus, more demanding when looking for a site to build their colony than when looking for a temporary site just for landing and resting, usually opting to occupy cavities. Swarms in urban areas are generally small, containing up to 20,000 bees, and show little defensive behavior, which facilitates the capture of bees in populous urban areas. Finally, we consider that our findings have practical and scientific implications, and that they are relevant for the development of an efficient strategy for controlling the population of Africanized honeybees in urban areas.

\section{Acknowledgments}

The authors thank CAPES for the grant of a doctoral scholarship, the Military Firefighters Corporation of Mossoro, RN for forwarding the requests of residents for swarm removal, and CETAPIS-RN and UFERSA for having provided the necessary conditions and materials for the development of the present study and for sending us climatological data.

\section{References}

Alves, J. J. A., Araújo, M. A. de, \& Nascimento, S. S. do. (2009). Degradação da Caatinga: uma investigação ecogeográfica. Revista Caatinga, 22(3), 126-135.

Baum, K. A., Tchakerian, M. D., Thoenes, S. C., \& Coulson, R. N. (2008). Africanized honey bees in urban environments: a spatio-temporal analysis. Landscape and Urban Planning, 85(2), 123-132. doi: 10. 1016/j.landurbplan.2007.10.005

Brandeburgo, M. A. M., \& Gonçalves, L. S. (1990). Environmental influence on the aggressive (defense) behaviour and colony development of Africanized bees (Apis mellifera). Ciência e Cultura (São Paulo), 42(10-12), 759-771.

Breed, M. D., Guzmán-Novoa, E., \& Hunt, G. J. (2004). Defensive behavior of honey bees: organization, genetics, and comparisons with other bees. Annual Reviews of Entomology, 49(1), 271-298. doi: 10. 1146/annurev.ento.49.061802.123155 
Brutscher, L. M., Baer, B., \& Niño, E. L. (2019). Putative drone copulation factors regulating honey bee (Apis mellifera) queen reproduction and health: A review. Insects, 10(1), 8. doi: 10.3390/insects10010008

Buchmann, S. L., \& Nabhan, G. P. (2012). The forgotten pollinators. Washington, D.C: Island Press.

Carmo, F. D., Fo., Espínola, J., Sobrinho, Maia, J. M., Neto, Carmo, F. L., Espinola, J., \& Maia, J. M. (1991). Dados meteorológicos de Mossoró: janeiro de 1989 a dezembro de 1990. (Coleção Mossoroense). Mossoró: Fundação Guimarães Duque.

Degrandi-Hoffman, G., Graham, H., Ahumada, F., Smart, M., \& Ziolkowski, N. (2019). The economics of honey bee (Hymenoptera: Apidae) management and overwintering strategies for colonies used to pollinate almonds. Journal of Economic Entomology, 112(6), 2524-2533. doi: 10.1093/jee/toz213

Domingos, H. G. T., \& Gonçalves, L. S. (2014). Termorregulação de abelhas com ênfase em Apis mellifera. Acta Veterinaria Brasilica, 8(3), 150-154. doi: 10.21708/avb.2014.8.3.3491

Domingos, H. G. T., Sombra, D. S., Santos, R. G., Gramacho, K. P., \& Gonçalves, L. S. (2018). Surface temperature and heat transfer between body regions of africanized honeybees (Apis mellifera L.) in hives under sun and shade conditions in the Northeastern Semi-arid Region of Brazil. Journal of Agricultural Science and Technology, 8(1), 28-35. doi: 10.17265/2161-6256/2018.01.004

Ferreira, R. S., Jr., Almeida, R. A. M. B., Barraviera, S. R. C. S., \& Barraviera, B. (2012). Historical perspective and human consequences of Africanized bee stings in the Americas. Journal of Toxicology and Environmental Health, Part B, 15(2), 97-108. doi: 10.1080/10937404.2012.645141

Foss, R. (2015). A self organising network model of information gathering by the honey bee swarm. Kybernetes, 44(3), 353-367. doi: 10.1108/K-112014-0264

Freitas, B. M., Sousa, R. M., \& Bomfim, G. A. (2007). Absconding and migratory behaviors of feral Africanized honey bee (Apis mellifera L.) colonies in NE Brazil. Acta Scientiarum. Biological Sciences, 29(4), 381-385. doi: 10.4025/actascibiolsci.v29i4.882

Grozinger, C. M., Richards, J., \& Mattila, H. R. (2014). From molecules to societies: mechanisms regulating swarming behavior in honey bees (Apis spp.). Apidologie, 45(3), 327-346. doi: 10.1007/s13592013-0253-2
Hall, D. M., \& Steiner, R. (2019). Insect pollinator conservation policy innovations at subnational levels: lessons for lawmakers. Environmental Science \& Policy, 93(3), 118-128. doi: 10.1016/j. envsci.2018.12. 026

Kasperek, K., Paleolog, J., Olszewski, K., Borsuk, G., \& Strachecka, A. (2012). Comparison of the defensive behaviour of Apis mellifera L. workers and the aggression of their queen sisters. Medycyna Weterynaryjna, 68(10), 589-593.

Kleinhenz, M., Bujok, B., Fuchs, S., \& Tautz, J. (2003). Hot bees in empty broodnest cells: heating from within. Journal of Experimental Biology, 206(23), 4217-4231. doi: 10.1242/jeb.00680

Lipinski, Z. (2019). Essences and mechanism of nest abandonment by honeybee swarms: swarming, absconding, migration and related phenomena. Olsztyn: Sprecograf.

Loiola, M. I. B., Roque, A. D. A., \& Oliveira, A. C. P. D. (2012). Caatinga: vegetação do semiárido brasileiro. Ecologia: Artigos de Divulgação, 4(1), 14-19.

Lopes, M. T. R., Barbosa, A. L., Vieira, J. M., Neto, Pereira, F. M., Camargo, R. C. R., Ribeiro, V. Q., \& Souza, B. A. (2011). Alternativas de sombreamento para apiários. Pesquisa Agropecuária Tropical, 41(3), 299-305. doi: 10.5216/pat.v41i3.8919

Maia-Silva, C., Silva, C. I., Hrncir, M., Queiroz, R. D., \& Imperatriz-Fonseca, V. L. (2012). Guia de plantas visitadas por abelhas na Caatinga. Fortaleza-CE: Editora Fundação Brasil Cidadão.

Malerbo-Souza, D. T., Nogueira-Couto, R. H., \& Couto, L. A. (2002). Características das colônias de abelhas africanizadas (Apis mellifera L.), coletadas de alojamentos naturais em Jaboticabal, Estado de São Paulo. Acta Scientiarum. Animal Sciences, 24(1), 863-867. doi: 10.4025/actascianimsci.v24i0.2331

Mello, M. H. S. H., Silva, E. A. da, \& Natal, D. (2003). Africanized bees in a metropolitan area of Brazil: shelters and climatic influences. Revista de Saúde Pública, 37(2), 237-241. doi: 10.1590/S0034-8910 2003000200012

Nascimento, D. J. (2019). Projeto SOS Abelhas Sergipe: resgate e georreferenciamento de enxames e colônias de abelhas Apis mellifera na Grande Aracaju. Monografia de graduação em Agroecologia, Instituto Federal de Sergipe, São Cristóvão, SE, Brasil.

Nisbet, C., Güler, A., \& Biyik, S. (2019). Effects of different environmental conditions on the cognitive function of honeybee (Apis mellifera L.) and mineral content of honey. Ankara Üniversitesi Veteriner 
Fakültesi Dergisi, 66(1), 95-101. doi: 10.1501/ Vetfak_0000002893

Pereira, D. S., Holanda, J. P., Neto, Sousa, L. C. F. S., Coelho, D. C., Silveira, D. S., \& Hernandez, L. M. (2014). Mitigação do comportamento de abandono de abelhas Apis mellifera L. em apiários no Semiárido Brasileiro. Acta Apicola Brasilica, 2(2), 1-11. doi: 10.18378/aab.v2i2.3507

Potts, S. G., Imperatriz-Fonseca, V., Ngo, H. T., Aizen, M. A., Biesmeijer, J. C., Breeze, T. D.,... Vanbergen, A. J. (2016). Safeguarding pollinators and their values to human well-being. Nature, 540(7632), 220-229. doi: 10.1038/nature20588

Sá, F. A., \& Sousa, P. H. A. A. (2019). Defensividade de abelhas Apis mellifera L. africanizadas. Revista Científica de Medicina Veterinária, 32(1), 1-9.

Santos, A. M. M., \& Mendes, E. C. (2016). Abelha africanizada (Apis mellifera L.) em áreas urbanas no brasil: necessidade de monitoramento de risco de acidentes. Revista Sustinere, 4(1), 117-143. doi: 10. 12957/sustinere.2016.24635

Santos, R. G., Domingos, H. G. T., Gramacho, K. P., \& Gonçalves, L. S. (2017). Sombreamento de colmeias de abelhas africanizadas no Semiárido Brasileiro. Revista Verde de Agroecologia e Desenvolvimento Sustentável, 12(5), 828-836. doi: 10.18378/rvads. v12i5.5407

Silva, F. G. R., \& Barreto, L. M. R. C. (2016). Resgate de enxames das regiões da Grande São Paulo. Mensagem Doce, 135(1), 7-13.
Souza, D. A. de, Gramacho, K. P., \& Castagnino, G. L. B. (2012). Produtividade de mel e comportamento defensivo como índices de melhoramento genético de abelhas africanizadas (Apis mellifera L.). Revista Brasileira de Saúde e Produção Animal, 13(2), 550557. doi: 10.1590/S1519-99402012000200022

Stabentheiner, A., Kovac, H., \& Brodschneider, R. (2010). Honeybee colony thermoregulation - regulatory mechanisms and contribution of individuals in dependence on age, location and thermal stress. PLoS One, 5(1), e8967. doi: 10.1371/ journal.pone. 0008967

Toledo, V. A. A., Toral, F. L. B., Miranda, S. B. de, Shiraishi, A., Hashimoto, J. H., \& Silva, W. R. (2006). Ocorrência e coleta de colônias e de enxames de abelhas africanizadas na zona urbana de Maringá, Estado do Paraná, Brasil. Acta Scientiarum. Animal Sciences, 28(3), 353-359. doi: 10.4025/ actascianimsci.v28i3.53

Wilson, J. S., \& Carril, O. J. M. (2015). The bees in your backyard: a guide to North America's bees. Princeton: Princeton University Press.

Winston, M. L. (1987). The biology of the honey bee. Cambridge: Harvard University Press.

Zaluski, R., Kadri, S. M., Souza, E. A., Silva, V. M. C., Silva, J. R. C., Rodrigues-Orsi, P., \& Orsi, R. O. (2014). Africanized honeybees in urban areas: a public health concern. Revista da Sociedade Brasileira de Medicina Tropical, 47(5), 659-662. doi: 10.1590/0037-8682-0254-2013 
